Louisiana State University

LSU Digital Commons

$1-1-2014$

\title{
Group 3 late embryogenesis abundant proteins from embryos of Artemia franciscana: Structural properties and protective abilities during desiccation
}

Leaf C. Boswell

Louisiana State University

Michael A. Menze

Eastern Illinois University

Steven C. Hand

Louisiana State University

Follow this and additional works at: https://digitalcommons.Isu.edu/biosci_pubs

\section{Recommended Citation}

Boswell, L., Menze, M., \& Hand, S. (2014). Group 3 late embryogenesis abundant proteins from embryos of Artemia franciscana: Structural properties and protective abilities during desiccation. Physiological and Biochemical Zoology, 87(5), 640-651. https://doi.org/10.1086/676936

This Article is brought to you for free and open access by the Department of Biological Sciences at LSU Digital Commons. It has been accepted for inclusion in Faculty Publications by an authorized administrator of LSU Digital Commons. For more information, please contact ir@lsu.edu. 
University of Louisville

ThinkIR: The University of Louisville's Institutional Repository

Faculty Scholarship

$8-14-2014$

\title{
Group 3 late embryogenesis abundant proteins from embryos of Artemia franciscana : structural properties and protective abilities during desiccation.
}

\author{
Leaf C. Boswell \\ Michael A. Menze \\ University of Louisville, michael.menze@louisville.edu \\ Steven C. Hand
}

Follow this and additional works at: https://ir.library.louisville.edu/faculty

Part of the Biology Commons

\section{ThinkIR Citation}

Boswell, Leaf C.; Menze, Michael A.; and Hand, Steven C., "Group 3 late embryogenesis abundant proteins from embryos of Artemia franciscana : structural properties and protective abilities during desiccation." (2014). Faculty Scholarship. 131.

https://ir.library.louisville.edu/faculty/131

This Article is brought to you for free and open access by ThinkIR: The University of Louisville's Institutional Repository. It has been accepted for inclusion in Faculty Scholarship by an authorized administrator of ThinkIR: The University of Louisville's Institutional Repository. For more information, please contact thinkir@louisville.edu. 


\section{Group 3 Late Embryogenesis Abundant Proteins from Embryos of Artemia franciscana: Structural Properties and Protective Abilities during Desiccation}

\author{
Leaf C. Boswell ${ }^{1, \star}$ \\ Michael A. Menze ${ }^{2}$ \\ Steven C. Hand \\ ${ }^{1}$ Division of Cellular, Developmental, and Integrative Biology, \\ Department of Biological Sciences, Louisiana State \\ University, Baton Rouge, Louisiana 70803; ${ }^{2}$ Department of \\ Biological Sciences, Eastern Illinois University, Charleston, \\ Illinois 61920
}

Accepted 3/30/2014; Electronically Published 8/14/2014

\begin{abstract}
Group 3 late embryogenesis abundant (LEA) proteins are highly hydrophilic, and their expression is associated with desiccation tolerance in both plants and animals. Here we show that two LEA proteins from embryos of Artemia franciscana, AfrLEA2 and AfrLEA3m, are intrinsically disordered in solution but upon desiccation gain secondary structure, as measured by circular dichroism. Trifluoroethanol and sodium dodecyl sulfate are both shown to induce $\alpha$-helical structure in AfrLEA2 and AfrLEA3m. Bioinformatic predictions of secondary-structure content for both proteins correspond most closely to conformations measured in the dry state. Because some LEA proteins afford protection to desiccation-sensitive proteins during drying and subsequent rehydration, we tested for this capacity in AfrLEA2 and AfrLEA3m. The protective capacities vary, depending on the target enzyme. For the cytoplasmic enzyme lactate dehydrogenase, neither AfrLEA2 nor AfrLEA3m, with or without trehalose present, was able to afford protection better than that provided by bovine serum albumin (BSA) under the same conditions. However, for another cytoplasmic enzyme, phosphofructokinase, both AfrLEA2 and AfrLEA3m in the presence of trehalose were able to afford protection far greater than that provided by BSA with trehalose. Finally, for the mitochondrial enzyme citrate synthase, $400-\mu \mathrm{g} / \mathrm{mL}$ AfrLEA3m without trehalose provided significantly more protection than the same concentration of either AfrLEA2 or BSA.
\end{abstract}

*Corresponding author; e-mail: lboswe1@lsu.edu.

Physiological and Biochemical Zoology 87(5):000-000. 2014. (C) 2014 by The University of Chicago. All rights reserved. 1522-2152/2014/8705-4012\$15.00. DOI: $10.1086 / 676936$

\section{Introduction}

Group 3 late embryogenesis abundant (LEA) proteins are a family of proteins accumulated by organisms in relation to water stress (Tunnacliffe and Wise 2007; Tunnacliffe et al. 2010; Hand et al. 2011). Major features of LEA proteins include high hydrophilicity and low sequence complexity (Cuming 1999; Tunnacliffe and Wise 2007; Hand et al. 2011). One well-characterized function attributed to LEA proteins is their ability to protect the activity of desiccation-sensitive enzymes against multiple types of water stress (for recent reviews, see Tunnacliffe and Wise 2007; Tunnacliffe et al. 2010; Hand et al. 2011; Hincha and Thalhammer 2012). Investigations into the secondary structure of LEA proteins reveal that the majority of LEA proteins are predominantly disordered in solution (Wolkers et al. 2001; Goyal et al. 2003; Shih et al. 2004, 2012; PouchkinaStantcheva et al. 2007; Tolleter et al. 2007; Thalhammer et al. 2010; Popova et al. 2011; Hundertmark et al. 2012) and gain structure upon desiccation (e.g., Goyal et al. 2003). Gain of well-defined secondary structure by LEA proteins during dehydration has led to the hypothesis that LEA proteins may function specifically in the dry state (e.g., Li and He 2009). Alternatively, there is also evidence that LEA proteins might function as unstructured proteins in the hydrated state. Several studies have shown that LEA proteins are able to reduce the aggregation of polyglutamine (polyQ) or amyloid $\beta$-peptide when coexpressed in mammalian cells (Chakrabortee et al. 2007, 2012; Liu et al. 2011). Marunde et al. (2013) showed that a group 1 LEA protein can improve cell viability and mitochondrial function at very modest levels of water stress, which are unlikely to promote substantial coiling of LEA proteins. Regardless of whether LEA proteins function in both hydrated and dry states, structural characterization is an important step in a comprehensive assessment of individual LEA proteins. We investigate the secondary structure of two group 3 LEA proteins present in embryos of Artemia franciscana, AfrLEA2 and AfrLEA3m, dried and in solution, as well as their capacity to adopt secondary structure after the addition of sodium dodecyl sulfate (SDS) or trifluoroethanol (TFE). In addition to structural studies, we tested the ability of recombinant AfrLEA2 and AfrLEA3m, both alone and in concert with trehalose, to afford protection to three different target enzymes during desiccation and subsequent rehydration.

It is well documented that group 2 LEA proteins have the ability to protect proteins against freezing (for review, see Tunnacliffe and Wise 2007), and protection during freezing has also been reported for group 3 LEA proteins, although not as 
extensively as for group 2 (Honjoh et al. 2000; Goyal et al. 2005). In addition to protection against water stress imposed by freezing, LEA proteins from groups $1-3$ can afford protection to enzymes during desiccation (Sanchez-Ballesta et al. 2004; Goyal et al. 2005; Grelet et al. 2005; Reyes et al. 2005). The ability of LEA proteins to protect the activity of desiccationsensitive enzymes from the deleterious effects of dehydration can, at least partially, be attributed to an ability to prevent enzyme aggregation (Goyal et al. 2005). Goyal et al. (2005) propose that the unordered, flexible structure of LEA proteins allows them to function as a physical barrier between aggregation-prone molecules, a function that they term "molecular shield" activity. Although protection against protein aggregation is imperative if an organism is to survive desiccation, prevention of protein denaturation must also be considered (Tompa and Kovacs 2010). Compared to those of classic chaperones, direct interactions between LEA proteins and target molecules are not as well characterized, but evidence for loose interaction has been reported (Nakayama et al. 2007).

In addition to protective macromolecules such as LEA proteins, anhydrobiotic organisms typically accumulate organic solutes such as trehalose, which aid in macromolecular protection during water stress (Yancey et al. 1982; Yancey 2005). Trehalose constitutes as much as $20 \%$ of the dry weight of $A$. franciscana embryos (Crowe et al. 1987). LEA proteins and trehalose in combination are capable of providing a synergistic protection to target molecules (Goyal et al. 2005). It is pertinent to note here that trehalose is not an absolute requirement for desiccation tolerance, because it is not accumulated by bdelloid rotifers (Lapinski and Tunnacliffe 2003; Caprioli et al. 2004) or various tardigrades (Hengherr et al. 2008); however, trehalose undoubtedly plays a role in the organisms in which it is accumulated. The importance of trehalose is exemplified in one organism that accumulates the sugar by the observation that Aphelenchus avenae is not able to survive desiccation unless ample time is provided for the conversion of glycogen to trehalose, as occurs during slow drying (Madin and Crowe 1975; Crowe et al. 1977). For AfrLEA2 and AfrLEA3m, our results demonstrate that these proteins are intrinsically disordered in solution, gain structure upon water restriction, and provide protection in a target-specific manner to proteins in the dried state; the effects are either additive or synergistic with the presence of trehalose.

\section{Methods}

\section{Recombinant LEA Proteins from Artemia franciscana}

As described in Hand et al. (2007) and Menze et al. (2009), AfrLEA2 (GenBank accession no. ACA47268.1) and AfrLEA3m (ACM16586.1) are designated group 3 LEA proteins on the basis of the classification scheme outlined by Wise (2003). Because the number of LEA proteins reported from animals continues to expand, a reclassification of groups could be warranted in the future. Preparation and purification of recombinant AfrLEA2 and AfrLEA3m were accomplished according to the procedures described in Boswell et al. (2014). Briefly, the orig- inal nucleic acid sequences were amplified from our existing complementary DNA library from A. franciscana and ligated into expression vectors, and then competent bacterial cells were transformed with the genes. AfrLEA2 was expressed with an $\mathrm{N}$-terminal 6X-His tag, and AfrLEA3m was expressed with a C-terminal 6X-His tag so as not to interfere with the mitochondrial localization sequence found at the $\mathrm{N}$-terminus. Bacterial cells were chemically lysed with Bugbuster Protein Extraction Reagent (Novagen, Rockland, MA) in the presence of a protease inhibitor cocktail (P8849; Sigma-Aldrich, St. Louis, $\mathrm{MO}$ ). Cellular debris was removed by centrifugation, and the resulting supernatant was subjected to affinity chromatography on a HisTrap FF crude column (GE Healthcare, Waukesha, WI) in a binding buffer composed of $20 \mathrm{mM}$ sodium phosphate, $0.5 \mathrm{M} \mathrm{NaCl}$, and $20 \mathrm{mM}$ imidazole, $\mathrm{pH}$ 7.5. Fractions containing recombinant protein were heat-treated at $95^{\circ} \mathrm{C}$ for 20 $\mathrm{min}$ and centrifuged $(20,000 \mathrm{~g}, 30 \mathrm{~min})$ to separate the soluble

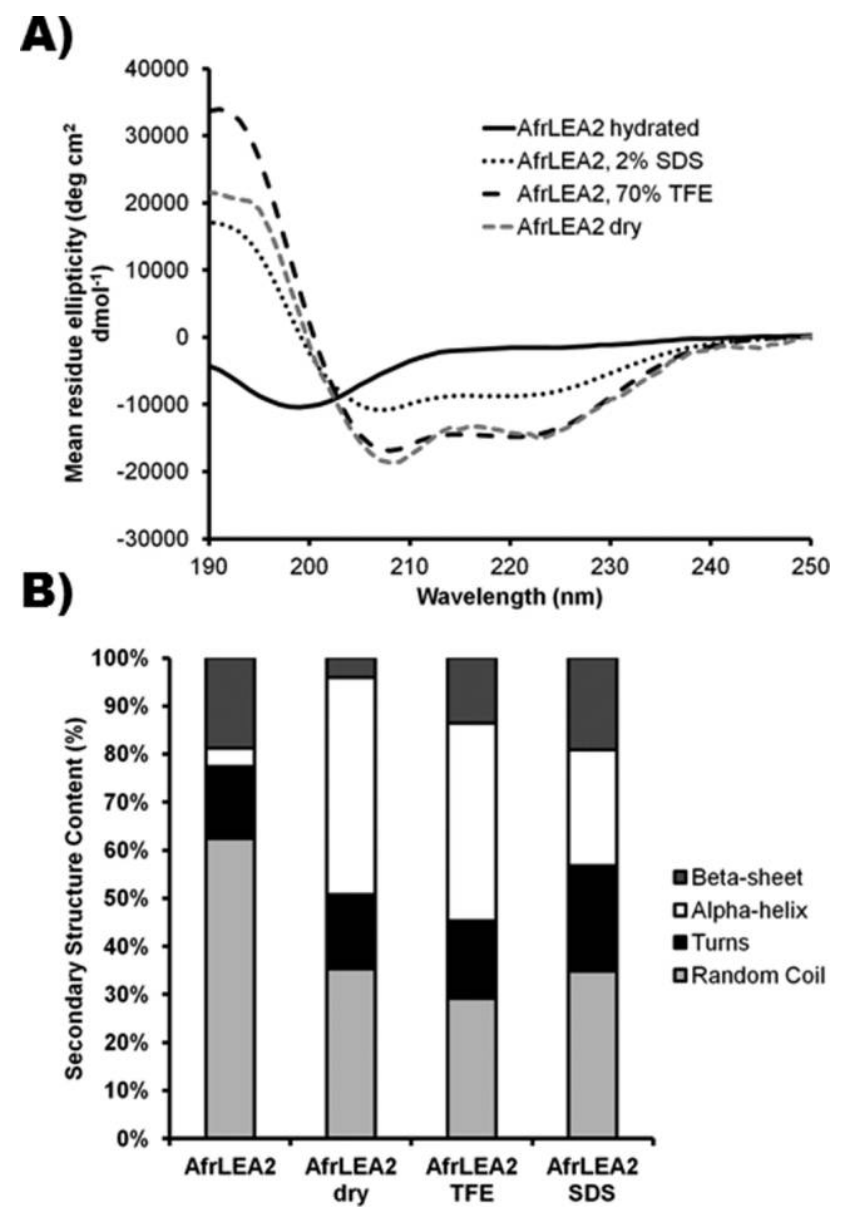

Figure 1. A, Circular dichroism (CD) spectra of recombinant AfrLEA2 in the hydrated state, in the presence of $2 \%$ sodium dodecyl sulfate (SDS) or $70 \%$ trifluoroethanol (TFE), and after desiccation. B, Structural composition of recombinant AfrLEA2, as calculated from the respective $\mathrm{CD}$ data for the hydrated protein, the protein exposed to $2 \%$ SDS or $70 \%$ TFE, and the dried protein. Algorithms used for the secondary-structure analyses are described in "Methods." 


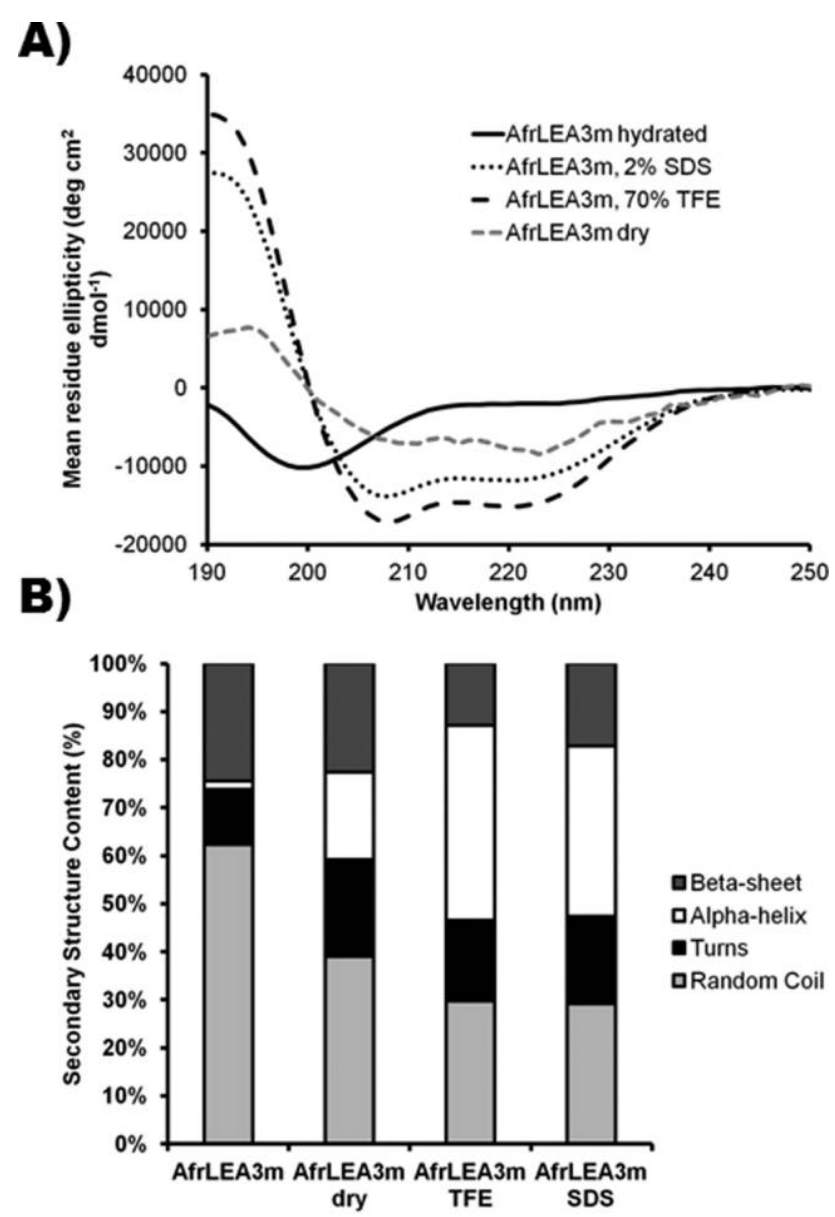

Figure 2. A, Circular dichroism (CD) spectra of recombinant AfrLEA3m in the hydrated state, in the presence of $2 \%$ sodium dodecyl sulfate (SDS) or $70 \%$ trifluoroethanol (TFE), and after desiccation. $B$, Structural composition of recombinant AfrLEA3m, as calculated from the respective $\mathrm{CD}$ data for the hydrated protein, the protein exposed to $2 \%$ SDS or $70 \%$ TFE, and the dried protein. Algorithms used for the secondary-structure analyses are described in "Methods."

fraction. The protein samples were then applied to an anion exchange column (HiTrap Q FF; GE Healthcare) in a starting buffer composed of $20 \mathrm{mM}$ triethanolamine and $10 \mathrm{mM} \mathrm{NaCl}$, $\mathrm{pH}$ 7.0. After elution, the fractions containing pure recombinant protein were exchanged into LEA storage buffer $(20 \mathrm{mM}$ Hepes, $50 \mathrm{mM} \mathrm{NaCl}, \mathrm{pH}$ 7.5) and concentrated using Amicon Ultra Centrifugal filters (Ultracel-10K; Millipore, Billerica, MA).

Recombinant AfrLEA2 has a total molecular mass of 43.1 $\mathrm{kDa}(38.9 \mathrm{kDa}$ plus $4.2 \mathrm{kDa}$ for a $6 \mathrm{X}-\mathrm{His}$ tag and associated vector sequence). AfrLEA3m is a mitochondrial LEA protein with a deduced molecular mass of $34.1 \mathrm{kDa}$, which includes the $3.2-\mathrm{kDa}$ mitochondrial targeting sequence.

\section{Far-Ultraviolet Circular Dichroism Spectroscopy}

Circular dichroism (CD) spectra were recorded on a Jasco J815 spectropolarimeter (Jasco Analytical Instruments, Easton,
$\mathrm{MD})$. The path length was $0.1 \mathrm{~cm}$, and measurements were taken for wavelengths from 190 to $250 \mathrm{~nm}$. Spectra were measured in a $10 \mathrm{mM}$ potassium phosphate buffer at protein concentrations of $0.14 \mathrm{mg} / \mathrm{mL}$ for recombinant AfrLEA2, $0.16 \mathrm{mg} /$ $\mathrm{mL}$ for recombinant AfrLEA3m, and $0.16 \mathrm{mg} / \mathrm{mL}$ for bovine serum albumin (BSA; Sigma Aldrich, product code A6003). The buffer (blank) spectrum was subtracted from each sample spectrum. After blank subtraction, each spectrum was converted to mean residue ellipticity and smoothed via the Savitzky-Golay method (Savitzky and Golay 1964), with a convolution width of 9 . Buffer subtraction, conversion to mean residue ellipticity, and smoothing were performed with the Spectra Manager software (Jasco Analytical Instruments). For measurements of dried proteins, $50 \mu \mathrm{L}$ of protein solution (at the respective concentrations above) were dried on one side of a demountable cuvette overnight in a dry box containing the desiccant Drierite (W. A. Hammond Drierite, Xenia, OH). A

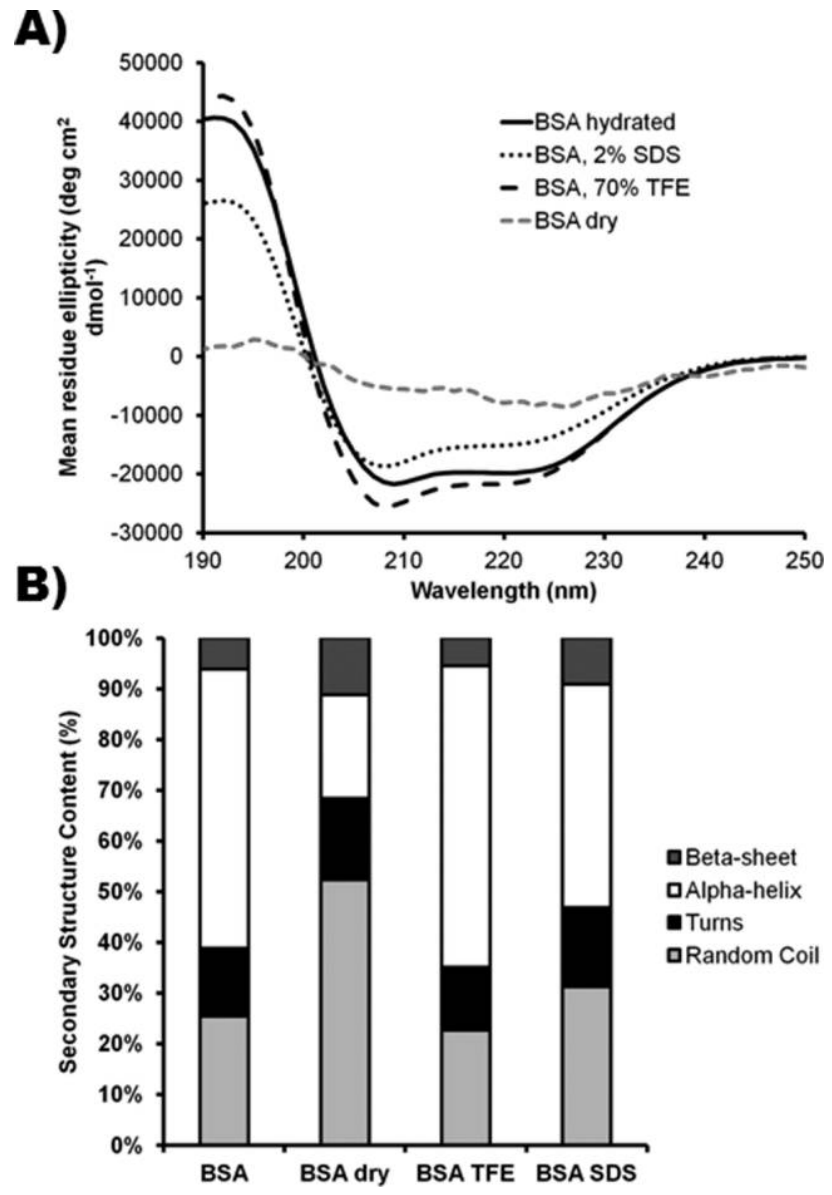

Figure 3. A, Circular dichroism (CD) analysis of bovine serum albumin (BSA) in the hydrated state, in the presence of $2 \%$ sodium dodecyl sulfate (SDS) or 70\% trifluoroethanol (TFE), and after desiccation. B, Structural composition of BSA as calculated from the respective $\mathrm{CD}$ data for the hydrated protein, the protein exposed to $2 \%$ SDS or $70 \%$ TFE, and the dried protein. Algorithms used for the secondary-structure analyses are described in "Methods." 


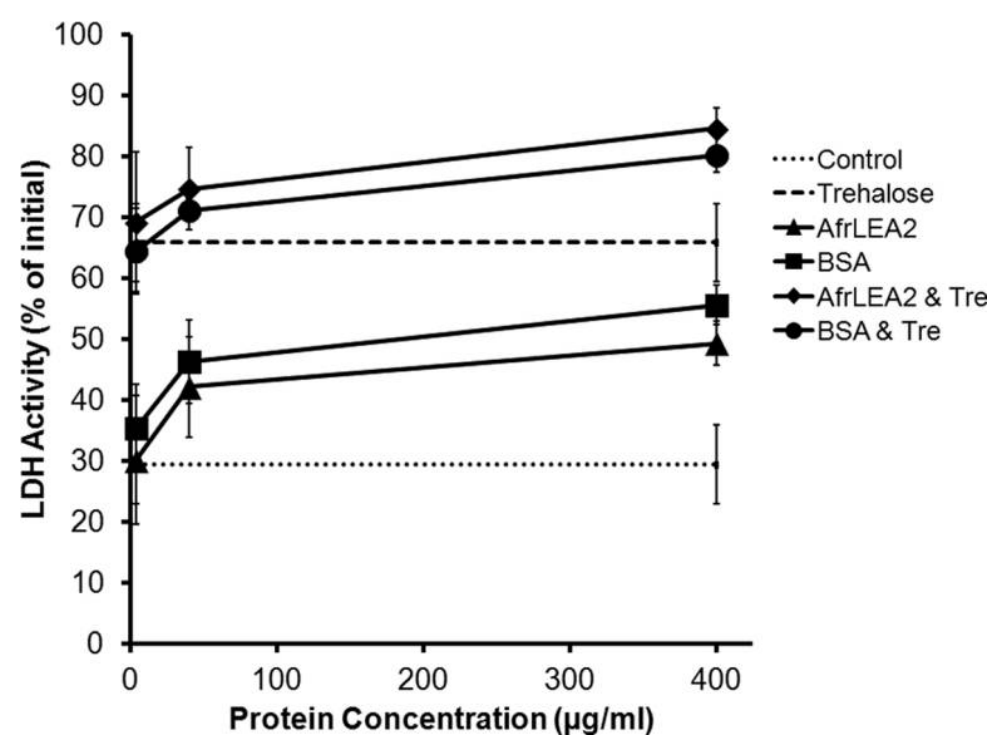

Figure 4. Residual lactate dehydrogenase (LDH) activity after desiccation for $1 \mathrm{wk}$ without additives (control) or in the presence of different protectants. Late embryogenesis abundant (LEA) protein concentrations were 4,40 , and $400 \mu \mathrm{g} / \mathrm{mL}$. The protective ability of AfrLEA2 both with and without $100 \mathrm{mM}$ trehalose (Tre) is compared to those of equivalent bovine serum albumin (BSA) solutions and $100 \mathrm{mM}$ trehalose alone. Values are reported as percent of the initial LDH activity measured before desiccation (mean \pm SD, $n=9$ ). A significant level of protection was provided by $100 \mathrm{mM}$ trehalose alone, compared to control (one-way ANOVA plus Tukey, $P<0.05$ ). The protection provided by $400-\mu \mathrm{g} / \mathrm{mL}$ BSA was slightly higher than that provided by $400-\mu \mathrm{g} / \mathrm{mL}$ AfrLEA2, but both provided significantly less protection than did trehalose alone (one-way ANOVA plus Tukey, $P<0.05$ ). Both $400-\mu \mathrm{g} / \mathrm{mL}$ AfrLEA2 plus trehalose and $400-\mu \mathrm{g} / \mathrm{mL}$ BSA plus trehalose provided a significantly higher level of protection than did trehalose alone (one-way ANOVA plus Tukey, $P<0.05$ ). Symbols to indicate significance have been omitted from the graph for clarity.

path length of $0.01 \mathrm{~cm}$ was used for conversion of dry data to mean residue ellipticity.

Secondary-structure analyses were performed with the DICHROWEB Web server (Whitmore and Wallace 2004, 2008), using the algorithms CONTINLL (Provencher and Glockner 1981; van Stokkum et al. 1990) and SELCON3 (Sreerama et al. 1999; Sreerama and Woody 2000). Reference data set 7 was used for all analyses because this data set is optimized for 190240-nm wavelengths and contains denatured proteins (Sreerama and Woody 2000).

\section{Desiccation and Activity Assays of Target Enzymes}

Lactate dehydrogenase (LDH) from rabbit muscle was obtained from Sigma Aldrich (product code L2500). Before use, LDH was exchanged into LEA storage buffer using Amicon Ultra Centrifugal filters (Ultracel-10K; Millipore). Then, $10-\mu \mathrm{L}$ droplets of $50-\mu \mathrm{g} / \mathrm{mL} \mathrm{LDH}$, with or without protectants, were dried at room temperature for $1 \mathrm{wk}$ in $1.5-\mathrm{mL}$ microcentrifuge tubes in a dry box containing Drierite. Samples were rehydrated on ice for $1 \mathrm{~h}$ with $20 \mu \mathrm{L}$ of LEA storage buffer (diluted twofold). Control assays of LDH activity were performed before desiccation by adding $5 \mu \mathrm{L}$ of $\mathrm{LDH}$ sample $(50 \mu \mathrm{g} / \mathrm{mL})$ to a final reaction volume of $1.0 \mathrm{~mL}$, which contained $0.2 \mathrm{M}$ Tris- $\mathrm{HCl}$ buffer (pH 7.3), $660 \mu \mathrm{M} \mathrm{NADH}$, and $3 \mathrm{mM}$ sodium pyruvate. $\mathrm{LDH}$ activity after desiccation was measured as described for controls, except that $10 \mu \mathrm{L}$ of $\mathrm{LDH}$ sample was added to ac- count for the twofold dilution of the enzyme during rehydration. Change in absorbance at $340 \mathrm{~nm}\left(\mathrm{~A}_{340}\right)$ was recorded for $1.5 \mathrm{~min}$, and LDH activity was reported as a percentage of the rate measured for nondried controls. Each sample was compared to control values that contained the same mixture of protectants in order to account for the increase in LDH activity observed in the presence of higher concentrations of protectant protein. It is appropriate to note that the use of $\mathrm{LDH}$ in droplets at up to $20 \mu \mathrm{g} / \mathrm{mL}$ yields artifactual results because of nonspecific binding of $\mathrm{LDH}$ protein to vial surfaces and timedependent inactivation that can readily be detected with control samples. Reported values are the average of three separate drying trials, each with three nested replicates $(n=9)$.

The phosphofructokinase (PFK) used in this study was a purified recombinant form of the rabbit muscle enzyme and was a generous gift from Dr. Simon Chang. Before use, PFK was exchanged into a $100 \mathrm{mM}$ sodium phosphate buffer $(\mathrm{pH}$ 8.0) containing $1 \mathrm{mM}$ ethylenediaminetetraacetic acid (EDTA) and $5 \mathrm{mM}$ dithiothreitol (DTT) using Amicon Ultra Centrifugal filters. Then $10-\mu \mathrm{L}$ droplets of $150-\mu \mathrm{g} / \mathrm{mL}$ PFK, with or without protectants, were dried at room temperature for $24 \mathrm{~h}$ in 1.5$\mathrm{mL}$ microcentrifuge tubes in a dry box containing Drierite. Samples were then rehydrated on ice for $1 \mathrm{~h}$ with $20 \mu \mathrm{L}$ of 50 $\mathrm{mM}$ sodium phosphate buffer $(\mathrm{pH} 8.0)$ containing $0.5 \mathrm{mM}$ EDTA and $2.5 \mathrm{mM}$ DTT. Following Carpenter and Crowe (1988), who reported residual activity of air-dried PFK in phosphate buffer as a function of water content (their fig. 5), we 


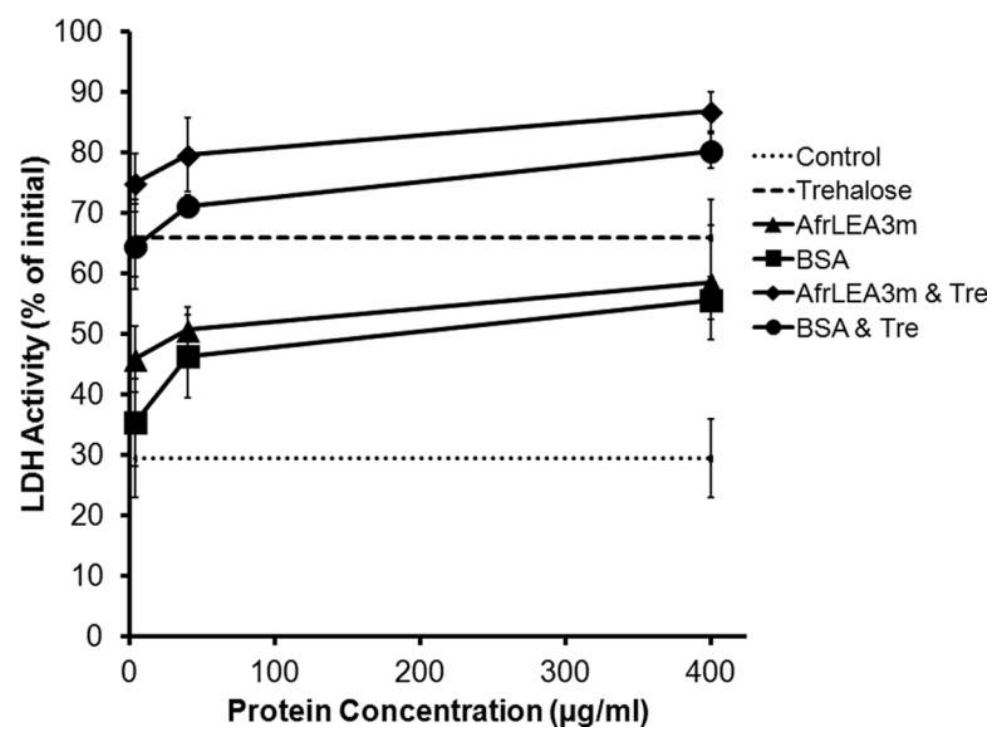

Figure 5. Residual lactate dehydrogenase (LDH) activity after desiccation for 1 wk without additives (control) or in the presence of different protectants. Late embryogenesis abundant (LEA) protein concentrations were 4,40 , and $400 \mu \mathrm{g} / \mathrm{mL}$. The protective ability of AfrLEA3m both with and without $100 \mathrm{mM}$ trehalose (Tre) is compared to those of equivalent bovine serum albumin (BSA) solutions and $100 \mathrm{mM}$ trehalose alone. Values are reported as percent of the initial LDH activity measured before desiccation (mean $\pm \mathrm{SD}, n=9$ ). A significant level of protection was provided by $100 \mathrm{mM}$ trehalose alone, compared to control (one-way ANOVA plus Tukey, $P<0.05$ ). Trehalose provided significantly higher protection than did $400-\mu \mathrm{g} / \mathrm{mL}$ BSA. Both $400-\mu \mathrm{g} / \mathrm{mL}$ AfrLEA3m plus trehalose and $400-\mu \mathrm{g} / \mathrm{mL}$ BSA plus trehalose provided a significantly higher level of protection than did trehalose alone (one-way ANOVA plus Tukey, $P<0.05$ ). Symbols to indicate significance have been omitted from the graph for clarity.

estimate the water content of our dried PFK samples to be approximately $3 \%-5 \%$ of the initial.

Activity was assayed essentially as described by Bock and Frieden (1974). Briefly, reactions (1-mL assay volume) were performed at $25^{\circ} \mathrm{C}$ in a $42 \mathrm{mM}$ Tris-acetate buffer $(\mathrm{pH} 8.0)$ containing $51 \mathrm{mM} \mathrm{KCl}$ and $5.1 \mathrm{mM} \mathrm{NH}_{4} \mathrm{Cl}$, with final concentrations of $0.16 \mathrm{mM} \mathrm{NADH}, 2 \mathrm{mM}$ ATP, $2 \mathrm{mM}$ fructose6-phosphate, $2 \mathrm{mM}$ magnesium acetate, 2.5 units of glycerol3-phosphate dehydrogenase (Sigma Aldrich, product code G6715), 25 units of triosephosphate isomerase (Sigma Aldrich, product code T2391), and 2 units of aldolase (Sigma Aldrich, product code A8811). Before use, all accessory enzymes were exchanged into a $100 \mathrm{mM}$ Tris-acetate buffer $\left(\mathrm{pH} \mathrm{8.0,} \mathrm{at} 6^{\circ} \mathrm{C}\right)$ with $0.1 \mathrm{mM}$ EDTA. PFK activity was measured for control samples before desiccation by adding $5 \mu \mathrm{L}$ of PFK sample (150 $\mu \mathrm{g} / \mathrm{mL}$ ) to a total reaction volume of $1 \mathrm{~mL}$ of the reaction mixture described above; for dried samples, $10 \mu \mathrm{L}$ of PFK was added to account for the twofold dilution of the enzyme during rehydration. Change in $\mathrm{A}_{340}$ was recorded for $2 \mathrm{~min}$, and PFK activity was reported as a percentage of the rate measured for nondried controls. Each sample was compared to control values that contained the same mixture of protectants in order to account for the increase in PFK activity observed in the presence of higher concentrations of protectant protein. Reported values are the average of three separate drying trials, each with three nested replicates $(n=9)$.

Citrate synthase (CS) from porcine heart was obtained from Sigma Aldrich (product code C3260). Before use, CS was ex- changed into $1 \mathrm{M}$ Tris- $\mathrm{HCl}$ ( $\mathrm{pH}$ 8.1) using Amicon Ultra Centrifugal filters. Then, $10-\mu \mathrm{L}$ droplets of $50-\mu \mathrm{g} / \mathrm{mL}$ CS, with or without protectants, were dried at room temperature for $24 \mathrm{~h}$ in a dry box containing Drierite. After one round of drying, each sample was resuspended with $10 \mu \mathrm{L} \mathrm{H}_{2} \mathrm{O}$ and dried a second time for $24 \mathrm{~h}$. "Double-dried" samples were rehydrated on ice for $1 \mathrm{~h}$ with $20 \mu \mathrm{L}$ of $0.5 \mathrm{M}$ Tris- $\mathrm{HCl}(\mathrm{pH} 8.1)$. Control CS activity assays were performed before desiccation by adding $5 \mu \mathrm{L}$ of CS sample $(50 \mu \mathrm{g} / \mathrm{mL})$ to a final reaction volume of $1 \mathrm{~mL}$, which contained $0.1 \mathrm{M}$ Tris- $\mathrm{HCl}$ buffer ( $\mathrm{pH} 8.1$ ), $0.1 \mathrm{mM} 5,5^{\prime}-$ dithiobis-(2-nitrobenzoic acid), and $0.2 \mathrm{mM}$ acetyl-CoA. The reaction was initiated by the addition of $0.5 \mathrm{mM}$ oxaloacetate. CS activity after desiccation was measured as described for controls, except that $10 \mu \mathrm{L}$ of CS sample was added to a final reaction volume of $1 \mathrm{~mL}$ in order to account for the twofold dilution of the enzyme during rehydration. Change in $\mathrm{A}_{340}$ was recorded for $2.0 \mathrm{~min}$, and CS activity was reported as a percentage of the rate measured for nondried controls. Each sample was compared to control values that contained the same mixture of protectants in order to account for the increase in CS activity observed in the presence of higher concentrations of protectant protein. Reported values are the average of three separate drying trials, each with three nested replicates $(n=9)$.

\section{Statistical Analysis}

A one-way ANOVA, paired with a Tukey post hoc test, was used in order to determine significance between treatment 


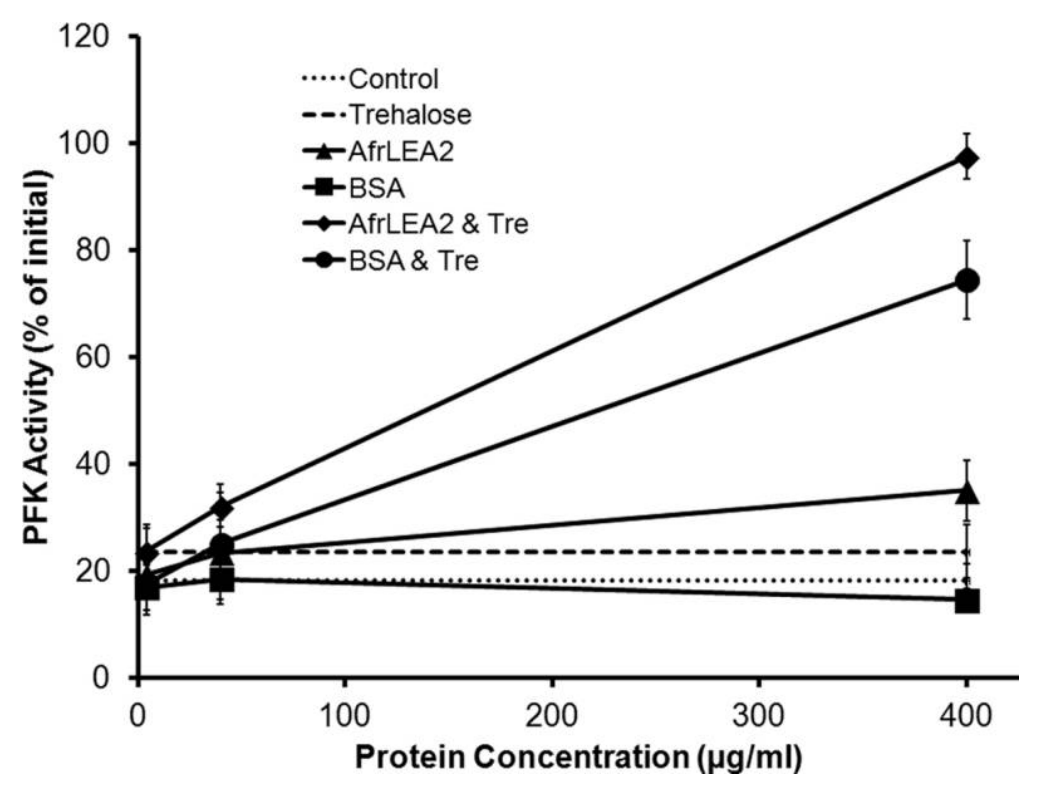

Figure 6. Residual phosphofructokinase (PFK) activity after desiccation for $24 \mathrm{~h}$ without additives (control) or in the presence of different protectants. Late embryogenesis abundant (LEA) protein concentrations were 4,40 , and $400 \mu \mathrm{g} / \mathrm{mL}$. The protective ability of AfrLEA2 both with and without $100 \mathrm{mM}$ trehalose (Tre) is compared to those of equivalent bovine serum albumin (BSA) solutions and $100 \mathrm{mM}$ trehalose alone. Values are reported as percent of the initial PFK activity measured before desiccation (mean $\pm \mathrm{SD}, n=9$ ). A significant level of protection was provided by $400-\mu \mathrm{g} / \mathrm{mL}$ AfrLEA2, compared to control, and $400-\mu \mathrm{g} / \mathrm{mL}$ BSA plus trehalose preserved more activity than did AfrLEA2 alone (one-way ANOVA plus Tukey, $P<0.05$ ). Of all treatments tested, $400-\mu \mathrm{g} / \mathrm{mL}$ AfrLEA2 plus trehalose preserved the highest residual PFK activity (one-way ANOVA plus Tukey, $P<0.05$ ). Symbols to indicate significance have been omitted from the graph for clarity.

groups for all enzyme drying studies (Prism; GraphPad Software, La Jolla, CA). Interaction between LEA proteins and trehalose was determined with a two-way ANOVA (SigmaPlot; Systat Software, San Jose, CA).

\section{Results}

\section{Secondary Structure of LEA Proteins}

In solution, the $\mathrm{CD}$ spectrum of AfrLEA2 exhibits features typical of a predominantly disordered, random-coiled protein with a minimal ellipticity at around $200 \mathrm{~nm}$ (fig. 1A). The presence of either $70 \%$ TFE or $2 \%$ SDS promotes AfrLEA2 to adopt substantial $\alpha$-helical structure, as indicated by spectra containing a double minimum near 208 and $222 \mathrm{~nm}$ and a strong positive band at $191 \mathrm{~nm}$ (fig. 1A). Secondary-structure estimates confirm the apparent gain of $\alpha$-helix content by AfrLEA2 in the presence of $2 \%$ SDS and $70 \%$ TFE, with an increase from $4 \% \alpha$-helix content in solution to $24 \%$ and $41 \%$, respectively (fig. $1 B$ ). AfrLEA2 in the dry state also exhibits spectral properties that are characteristic of $\alpha$-helix, and the spectrum is quite similar to that induced by the presence of TFE (fig. 1A). Desiccation of AfrLEA2 causes an increase in $\alpha$ helix content from $4 \%$ in solution to $46 \%$ dry, as determined from the CD spectra (fig. 1B).

Similar to what was observed for AfrLEA2, AfrLEA3m was found to be predominantly disordered in solution, with a propensity to adopt a more $\alpha$-helical structure in 2\% SDS or 70\% TFE solutions (fig. 2A); $\alpha$-helix content increases from $2 \%$ for the hydrated protein to $41 \%$ and $36 \%$, respectively (fig. $2 B$ ). Drying of AfrLEA3m does not seem to induce a structural shift in the CD spectra as large as that seen for AfrLEA2 (fig. 2A), but the secondary-structure estimation indicates that $\alpha$-helix content does increase notably, from $2 \%$ in solution to $18 \%$ dry (fig. $2 B$ ). AfrLEA3m possesses a greater percentage of $\beta$-sheet in the dry state than does AfrLEA2, which could explain the lower $\alpha$-helix content of AfrLEA3m. Finally, it is appropriate to note that both recombinant proteins contain approximately $10 \%$ sequence that is atypical of mature LEA protein. AfrLEA2 contains a $4.2-\mathrm{kDa}$ segment that represents the $6 \mathrm{X}-\mathrm{His}$ tag and associated vector sequence, while the AfrLEA3m protein includes a hydrophobic targeting sequence of $3.2 \mathrm{kDa}$.

CD spectroscopy measurements were also gathered for the globular protein BSA. BSA spectra served two purposes: first, as a control protein to check the accuracy of both CD measurements and deconvolution software and second, as a control protein against which we could compare the structural changes of AfrLEA2 and AfrLEA3m. The spectrum of BSA in solution was that of a predominantly $\alpha$-helical protein (fig. $3 A$ ). Takeda et al. (1987) estimated the secondary structure of BSA to contain $66 \% \alpha$-helix, 3\% $\beta$-sheet, and 31\% random coil. Secondary-structure estimates from our CD data are similar: $56 \% \alpha$ helix, $6 \% \beta$-sheet, and $26 \%$ random coil. The presence of either $2 \%$ SDS or $70 \%$ TFE did not cause a substantial shift in the BSA spectrum (fig. $3 A$ ). However, drying did shift the CD spectra of BSA (fig. $3 A$ ), but toward a pattern that indicates a greater percentage of random coil $(26 \%$ in solution vs. $52 \%$ 


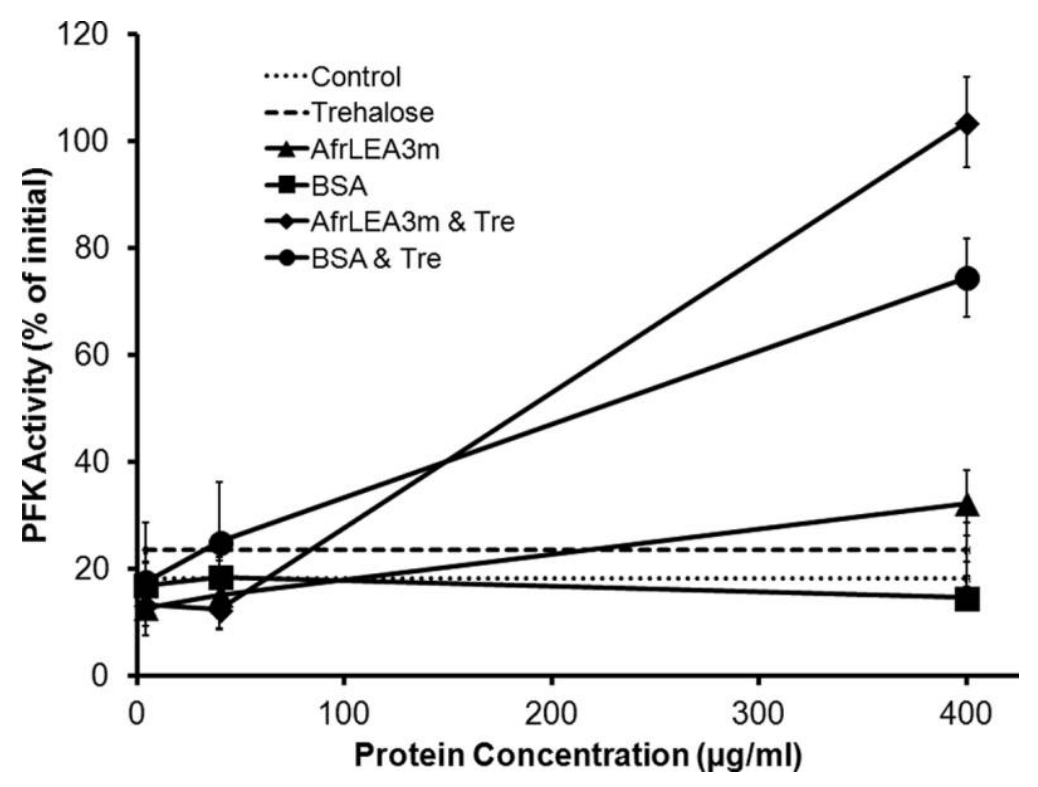

Figure 7. Residual phosphofructokinase (PFK) activity after desiccation for $24 \mathrm{~h}$ without additives (control) or in the presence of different protectants. Late embryogenesis abundant (LEA) protein concentrations were 4,40 , and $400 \mu \mathrm{g} / \mathrm{mL}$. The protective ability of AfrLEA3m both with and without $100 \mathrm{mM}$ trehalose (Tre) is compared to those of equivalent bovine serum albumin (BSA) solutions and $100 \mathrm{mM}$ trehalose alone. Values are reported as percent of the initial PFK activity measured before desiccation (mean \pm SD, $n=9$ ). A significant level of protection was afforded by $400-\mu \mathrm{g} / \mathrm{mL}$ BSA plus trehalose, compared to control, and $400-\mu \mathrm{g} / \mathrm{mL}$ AfrLEA3m plus trehalose provided a significantly higher level of protection than did any other treatment (one-way ANOVA plus Tukey, $P<0.05$ ). Symbols to indicate significance have been omitted from the graph for clarity.

when dry; fig. $3 B$ ). This spectrum change is consistent with denaturation of the globular protein in the dried state.

\section{Protection of Enzyme Activity by LEA Proteins during Desiccation}

Drying studies with combinations of target enzyme and LEA protein were performed to test the protective abilities of the two recombinant AfrLEA proteins against dehydration-induced damage. To evaluate whether a cytoplasmic LEA protein preferentially protects cytoplasmic enzymes while a mitochondrial LEA protein preferentially protects mitochondria-localized enzymes, we used a mix-and-match design by choosing target enzymes that reside in each of these compartments.

After desiccation and storage in the dry state for $1 \mathrm{wk}, \mathrm{LDH}$, when rehydrated, exhibits a residual activity of $31 \% \pm 8 \%$ (mean $\pm \mathrm{SD}$ ), compared to nondried control activity (figs. $4,5)$. The residual activity of $\mathrm{LDH}$ increases to $66 \% \pm 6 \%$ (mean $\pm \mathrm{SD}$ ) when dried in the presence of $100 \mathrm{mM}$ trehalose. The protection afforded LDH by the two LEA proteins is significant and similar to but not statistically different from the protection seen with BSA (one-way-ANOVA plus Tukey, $P>$ $0.05)$, both in the presence and in the absence of $100 \mathrm{mM}$ trehalose (figs. 4, 5).

PFK is considered one of the most dehydration-sensitive enzymes known (Crowe et al. 1987). It is completely and irreversibly inactivated during freeze-drying (Carpenter et al. 1987; Carpenter and Crowe 1989) and during air-drying to no more than $3 \%$ initial sample water (superfused with $\mathrm{CaSO}_{4}$ dried nitrogen at $33^{\circ}-35^{\circ} \mathrm{C}$; Carpenter and Crowe 1988), perhaps because of the formation of inactive dimers (Crowe et al. 1992). After drying at room temperature for $24 \mathrm{~h}$, PFK displays a residual activity of $18 \% \pm 3 \%$ (mean $\pm \mathrm{SD}$ ), which is increased only to $24 \% \pm 5 \%$ in the presence of $100 \mathrm{mM}$ trehalose (figs. 6, 7). AfrLEA2 and AfrLEA3m again perform similarly, but both LEA proteins protect PFK far better than does BSA with or without trehalose. In fact, BSA alone does not afford any protection to PFK, while a remarkable 98\% \pm $4 \%$ of control (nondried) activity is preserved when the enzyme is dried in the presence of $400-\mu \mathrm{g} / \mathrm{mL}$ AfrLEA2 plus $100 \mathrm{mM}$ trehalose (fig. 6), and $103 \% \pm 8 \%$ of control activity is preserved when PFK is dried in the presence of $400-\mu \mathrm{g} / \mathrm{mL}$ AfrLEA3m plus $100 \mathrm{mM}$ trehalose (fig. 7). To our knowledge, this is the first time the protective ability of LEA proteins has been tested with a target protein possessing such high sensitivity to desiccation.

Finally, we tested the mitochondrial enzyme CS, which was double-dried (see "Desiccation and Activity Assays of Target Enzymes") before each assay for residual activity. CS retains $20 \% \pm 3 \%$ of control activity after the final rehydration (figs. $8,9)$. Trehalose provides a high level of protection to CS, as evidenced by a residual activity of $76 \% \pm 5 \%$. As seen with the target enzyme LDH, the protective abilities of the two LEA proteins plus $100 \mathrm{mM}$ trehalose are similar to but are not statistically different from the protection observed with BSA plus trehalose (one-way ANOVA plus Tukey, $P>0.05$ ). However, the presence 


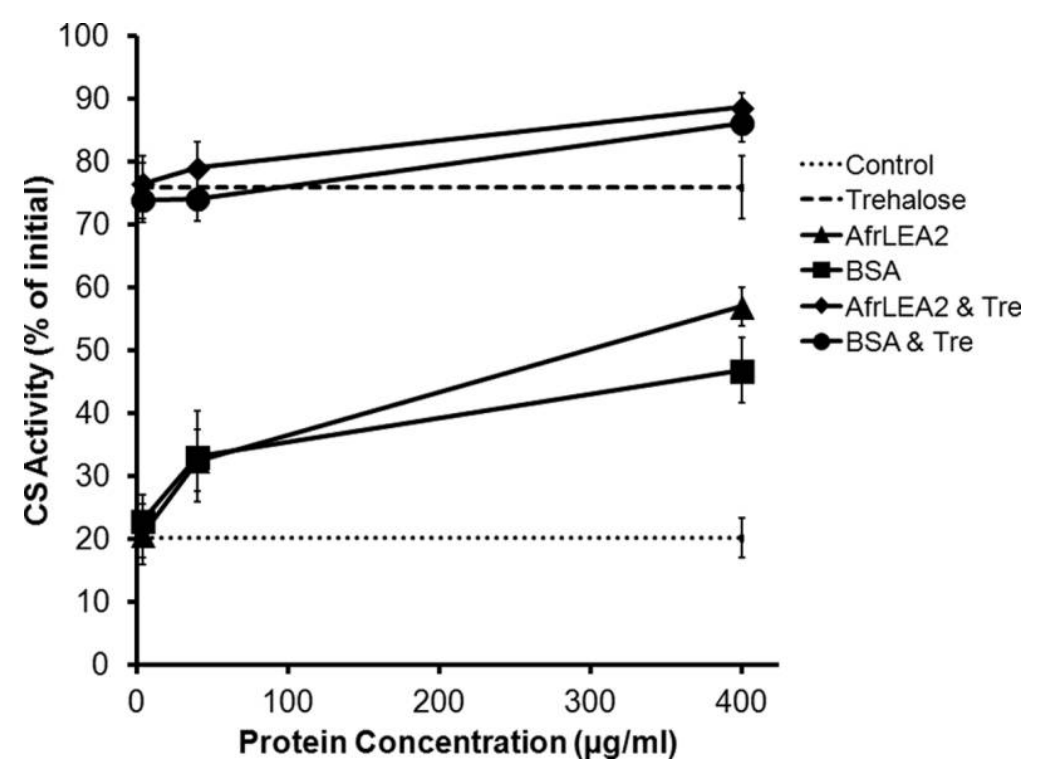

Figure 8. Residual citrate synthase (CS) activity after "double drying" without additives (control) or in the presence of different protectants. Late embryogenesis abundant (LEA) protein concentrations were 4,40 , and $400 \mu \mathrm{g} / \mathrm{mL}$. The protective ability of AfrLEA2 both with and without $100 \mathrm{mM}$ trehalose (Tre) is compared to those of equivalent bovine serum albumin (BSA) solutions and $100 \mathrm{mM}$ trehalose alone. Values are reported as percent of the initial CS activity measured before desiccation (mean $\pm \mathrm{SD}, n=9$ ). A significant level of protection was provided by $100 \mathrm{mM}$ trehalose alone, compared to $400-\mu \mathrm{g} / \mathrm{mL}$ AfrLEA2, which in turn provided a higher level of protection than did $400-\mu \mathrm{g} /$ $\mathrm{mL}$ BSA (one-way ANOVA plus Tukey, $P<0.05$ ). The protection provided by both $400-\mu \mathrm{g} / \mathrm{mL}$ AfrLEA2 plus trehalose and $400-\mu \mathrm{g} / \mathrm{mL}$ BSA plus trehalose was significantly higher than that provided by trehalose alone (one-way ANOVA plus Tukey, $P<0.05$ ). Symbols to indicate significance have been omitted from the graph for clarity.

of $400-\mu \mathrm{g} / \mathrm{mL}$ AfrLEA3m alone protects $69 \% \pm 4 \%$ of the control CS activity (fig. 9), which is significantly more protection than is provided by the same concentration of either AfrLEA2 or BSA (one-way ANOVA plus Tukey, $P<0.05$; fig. 8).

\section{Discussion}

Despite the high content of $\alpha$-helix predicted by bioinformatics software (Hand et al. 2007; Menze et al. 2009), both recombinant AfrLEA2 and AfrLEA3m are predominantly disordered in solution. This intrinsic disorder in the hydrated state is a common theme for LEA proteins and is attributed to their highly hydrophilic nature (Tunnacliffe and Wise 2007). Both AfrLEA2 and AfrLEA3m adopt an increased percentage of $\alpha$ helical structure in the presence of SDS and TFE and also are found to gain structure in the dried state. The ability of LEA proteins to gain structure after drying was first documented by Wolkers et al. (2001). We also show that both AfrLEA2 and AfrLEA3m protect sensitive enzymes from the damage imposed by desiccation, thereby preserving enzyme activity that is typically lost after drying.

The ability of AfrLEA2 and AfrLEA3m to gain structure during drying is in agreement with recent studies on LEA proteins (for review, see Tunnacliffe and Wise 2007; Tunnacliffe et al. 2010; Hand et al. 2011; Hincha and Thalhammer 2012). A predominant lack of secondary structure in solution places LEA proteins within a large class of proteins most commonly called intrinsically disordered proteins, or IDPs (for review, see Uver- sky and Dunker 2010). Buffer solutions containing 70\% TFE were used in order to probe the conformational propensities of recombinant AfrLEA2 and AfrLEA3m. Both recombinant LEA proteins were found to gain $\alpha$-helical structure in the presence of $70 \% \mathrm{TFE}$, while the secondary structure of the control protein BSA remained effectively unchanged. Although the exact mechanism through which this desolvating agent promotes secondary structure is debated, $\alpha$-helix induction is thought to be due largely to desolvation of the polypeptide backbone (Kentsis and Sosnick 1998). Therefore, it can be argued that the promotion of $\alpha$-helical structure in AfrLEA2 and AfrLEA3m by TFE is pertinent to the secondary structure gained during desiccation. SDS was also found to induce $\alpha$ helical structure in both AfrLEA2 and AfrLEA3m, although not as effectively as TFE. The induction of $\alpha$-helical structure in LEA proteins by SDS has been previously documented (Ismail et al. 1999; Shih et al. 2004, 2012; Tolleter et al. 2007).

The spectra for AfrLEA2 and AfrLEA3m in the dried state indicate that both proteins gain structure during desiccation. AfrLEA2 adopts substantial $\alpha$-helical structure, while AfrLEA3m gains both $\alpha$-helix and turns. In contrast, BSA becomes more disordered during drying. This observed loss of structure suggests denaturation, which would not be unusual for a globular protein such as BSA. Of the three conditions evaluated by CD in the present study (TFE, SDS, and dried), the $\alpha$-helix content of $59 \%$ predicted for AfrLEA2 by bioinformatics software best matches the content observed for the 


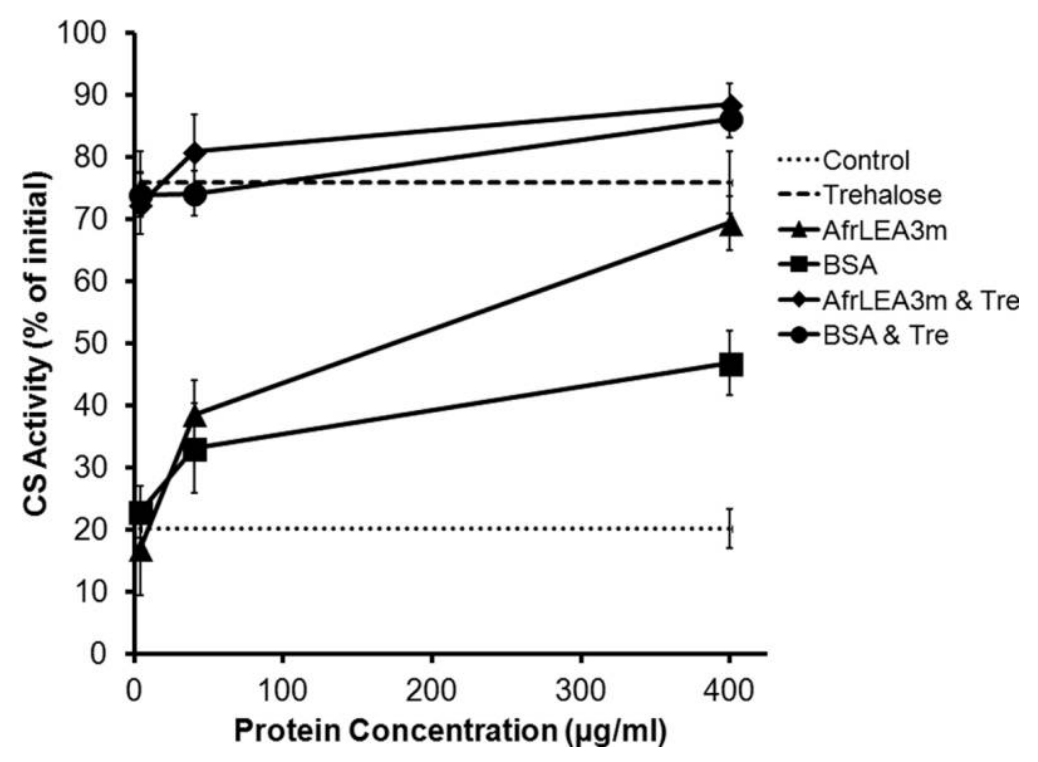

Figure 9. Residual citrate synthase (CS) activity after "double drying" without additives (control) or in the presence of different protectants. Late embryogenesis abundant (LEA) protein concentrations were 4, 40, and $400 \mu \mathrm{g} / \mathrm{mL}$. The protective ability of AfrLEA3m both with and without $100 \mathrm{mM}$ trehalose (Tre) is compared to those of equivalent bovine serum albumin (BSA) solutions and $100 \mathrm{mM}$ trehalose alone. Values are reported as percent of the initial CS activity measured before desiccation (mean $\pm \mathrm{SD}, n=9$ ). A significant level of protection was provided by $100 \mathrm{mM}$ trehalose alone, compared to $400-\mu \mathrm{g} / \mathrm{mL}$ AfrLEA3m, which in turn provided a higher level of protection than did $400-$ $\mu \mathrm{g} / \mathrm{mL}$ BSA (one-way ANOVA plus Tukey, $P<0.05$ ). The protection provided by both $400-\mu \mathrm{g} / \mathrm{mL}$ AfrLEA3m plus trehalose and $400-\mu \mathrm{g} / \mathrm{mL}$ BSA plus trehalose was significantly higher than that provided by trehalose alone (one-way ANOVA plus Tukey, $P<0.05$ ). Symbols to indicate significance have been omitted from the graph for clarity.

dried state $(45.6 \%)$. This outcome is consistent with the general case that predictive algorithms, when applied to LEA protein, often predict the structure of the dried molecule (Tolleter et al. 2007; Thalhammer et al. 2010; Popova et al. 2011). In contrast to AfrLEA2, AfrLEA3m is predicted to contain $73 \% \alpha$ helix but, on the basis of CD spectroscopy, adopts only $18 \%$ $\alpha$-helix when desiccated. Secondary structure of a group 3 LEA protein from pollen was shown to be dependent on both the speed of drying and the presence of sucrose (Wolkers et al. 2001). Rapid drying, as opposed to the slow drying performed for AfrLEA2 and AfrLEA3m, promoted a higher proportion of $\alpha$-helical structure (Wolkers et al. 2001). Changes in ionic composition can also affect secondary structure of LEA proteins (Furuki et al. 2011). How such factors might alter the final dried structures of AfrLEA2 and AfrLEA3m should be tested in the future.

As discussed above, gain of structure upon desiccation has led to the prediction that LEA proteins may function preferentially in the dry state. However, the ability of LEA proteins to prevent protein aggregation also has been shown in solution (e.g., Chakrabortee et al. 2007). Thus, it appears more likely that LEA proteins are functional across a broad range of hydration states, although the nature of the protection conferred could differ. For example, an individual LEA protein could function as a molecular shield in solution, and the same LEA protein could gain structure as water is removed to further protect the cell in the dry state by interacting with membranes, stabilizing sugar glasses, and forming filamentous networks (for extended reviews, see Tunnacliffe and Wise 2007; Hand et al. 2011).

We have shown that the capacity of AfrLEA2 and AfrLEA3m to protect desiccation-sensitive target enzymes from damage during drying depends on the target protein tested. For LDH, neither AfrLEA2 nor AfrLEA3m was able to afford protection better than that provided by BSA, which is in apparent contrast with reports for certain LEA proteins in the literature (Goyal et al. 2005). However, closer inspection reveals that AfrLEA2 and AfrLEA3m did afford a high degree of protection to LDH, similar to that reported by Goyal et al. (2005), but the difference is that we found BSA to stabilize LDH far more than previously reported. Small differences in the final water content of dried samples could explain this inconsistency. Reyes et al. (2005) reported that, in the presence of BSA, LDH exhibited $75 \%$ residual activity after being dried to $2 \%$ water content but activity dropped below $40 \%$ at a water content of less than $2 \%$. Another aspect that has differed substantially among studies is the concentration of LDH in the test mixture. In our study, $\mathrm{LDH}$ was dried at an initial concentration of $50 \mu \mathrm{g} / \mathrm{mL}$ because preliminary observations showed that at lower concentrations the enzyme lost activity in a time-dependent fashion when simply stored on ice for $1 \mathrm{~h}$ during rehydration (data not shown). In comparison, multiple groups have dried or frozen $\mathrm{LDH}$ at concentrations lower than $10 \mu \mathrm{g} / \mathrm{mL}$ (Miller et al. 1998; Honjoh et al. 2000; Sanchez-Ballesta et al. 2004; Goyal et al. 2005; Reyes et al. 2005; Nakayama et al. 2007). The use of such 
low concentrations of LDH could result in nonspecific ad $\rightarrow$ Boswell L.C., D.S. Moore, and S.C. Hand. 2014. Quantification sorption of $\mathrm{LDH}$ to vial surfaces.

In our study, AfrLEA2 and AfrLEA3m, when combined with trehalose, are able to protect nearly $100 \%$ of control PFK activity when rehydrated $24 \mathrm{~h}$ after desiccation, and this protection is far greater than that seen with BSA plus trehalose. Fur $\rightarrow$ thermore, the combined effect of LEA protein and trehalose is synergistic, compared to that of either of the agents alone; significant interaction between LEA protein and trehalose was confirmed (two-way ANOVA, $P<0.001$ ). The stabilization of PFK with trehalose alone is virtually identical to that reportec by Carpenter et al. (1987) under their "slow-drying" regime, which is very similar to the drying conditions we used here. Results for the two cytosolic enzymes tested (LDH and PFK, do not indicate that a cytosolic LEA protein is able to provide better protection to cytosolic enzymes than is a mitochondrial LEA protein.

Compared to PFK, CS shows significant resistance to desiccation damage and therefore was "double-dried" in order to cause more perturbation to the enzyme. This double-drying technique has been utilized previously with CS (e.g., see Pouch kina-Stantcheva et al. 2007). The protective abilities of the two LEA proteins when combined with trehalose are similar to each other and also to that of BSA plus trehalose. However, AfrLEA3m alone, at the highest concentration tested, provided significantly more protection to CS than did AfrLEA2 or BSA A somewhat similar situation of preferential protection has been reported for the interaction of a LEA protein with lipid membranes, where a mitochondria-targeted LEA protein preferentially protected liposomes with a lipid composition that mimicked the endogenous composition of the inner mitochondrial membrane, as compared to liposomes with a more generic composition (Tolleter et al. 2010). of cellular protein expression and molecular features of group 3 LEA proteins from embryos of Artemia franciscana. Cell Stress Chaperones 19:329-341. doi:10.1007/s12192-013 -0458-3.

$\rightarrow$ Caprioli M., A.K. Katholm, G. Melone, H. Ramlov, C. Ricci, and N. Santo. 2004. Trehalose in desiccated rotifers: a comparison between a bdelloid and a monogonont species. Comp Biochem Physiol A 139:527-532. doi:10.1016/j.cbpb.2004 .10 .019 .

$\rightarrow$ Carpenter J.F. and J.H. Crowe. 1988. Modes of stabilization of a protein by organic solutes during desiccation. Cryobiology 25:459-470. doi:10.1016/0011-2240(88)90054-5.

1989. An infrared spectroscopic study of the interactions of carbohydrates with dried proteins. Biochemistry 28: 3916-3922. doi:10.1021/bi00435a044.

$\rightarrow$ Carpenter J.F., B. Martin, L.M. Crowe, and J.H. Crowe. 1987. Stabilization of phosphofructokinase during air-drying with sugars and sugar transition/metal mixtures. Cryobiology 24: 455-464. doi:10.1016/0011-2240(87)90049-6.

$\rightarrow$ Chakrabortee S., C. Boschetti, L.J. Walton, S. Sarkar, D.C. Rubinsztein, and A. Tunnacliffe. 2007. Hydrophilic protein associated with desiccation tolerance exhibits broad protein stabilization function. Proc Natl Acad Sci USA 104:1807318078. doi:10.1073/pnas.0706964104.

$\rightarrow$ Chakrabortee S., Y. Liu, L. Zhang, H.R. Matthews, H.R. Zhang, N. Pan, C.R. Cheng, et al. 2012. Macromolecular and smallmolecule modulation of intracellular $\mathrm{A} \beta_{42}$ aggregation and associated toxicity. Biochem J 442:507-515. doi:10.1042 /bj20111661.

Crowe J.H., L.M. Crowe, J.F. Carpenter, and C.A. Wistrom. 1987. Stabilization of dry phospholipid bilayers and proteins by sugars. Biochem J 242:1-10.

In conclusion, AfrLEA2 and AfrLEA3m are intrinsically dis $\rightarrow$ Crowe J.H., F.A. Hoekstra, and L.M. Crowe. 1992. Anhydroordered proteins that gain secondary-structural motifs upon desiccation. In addition, both proteins are able to protect des-

iccation-sensitive enzymes from the deleterious effects of des $\rightarrow$ Crowe J.H., K.A.C. Madin, and S.H. Loomis. 1977. Anhydroiccation and subsequent rehydration. These findings serve not only to further define the molecular characteristics and possible functions of AfrLEA2 and AfrLEA3m but also to add to the pool of evidence that supports a role for LEA proteins in desiccation tolerance. biosis. Annu Rev Physiol 54:579-599. doi:10.1146/annurev .physiol.54.1.579. biosis in nematodes: metabolism during resumption of activity. J Exp Zool 201:57-63. doi:10.1002/jez.1402010107.

Cuming A.C. 1999. LEA proteins. Pp. 753-780 in R.P. Shewry and R. Casey, eds. Seed proteins. Kluwer, Boston.

$\rightarrow$ Furuki T., T. Shimizu, T. Kikawada, T. Okuda, and M. Sakurai. 2011. Salt effects on the structural and thermodynamic properties of a group 3 LEA protein model peptide. Biochemistry

\section{Acknowledgments} 50:7093-7103. doi:10.1021/bi200719s.

This work was supported by the National Science Foundation (grant IOS-0920254). Thanks are extended to Dr. Ted J. Gauthier of the H. D. Wilson Laboratories at Louisiana State University for assistance with circular dichroism spectroscopy.

\section{Literature Cited}

$\rightarrow$ Goyal K., L. Tisi, A. Basran, J. Browne, A. Burnell, J. Zurdo, and A. Tunnacliffe. 2003. Transition from natively unfolded to folded state induced by desiccation in an anhydrobiotic nematode protein. J Biol Chem 278:12977-12984. doi:10 $.1074 /$ jbc.M212007200.

$\rightarrow$ Goyal K., L.J. Walton, and A. Tunnacliffe. 2005. LEA proteins prevent protein aggregation due to water stress. Biochem J 388:151-157. doi:10.1042/bj20041931.

$\rightarrow$ Bock P.E. and C. Frieden. 1974. pH-induced cold lability o $\rightarrow$ Grelet J., A. Benamar, E. Teyssier, M.H. Avelange-Macherel, D. rabbit skeletal muscle phosphofructokinase. Biochemistry 13: 4191-4196. doi:10.1021/bi00717a020. Grunwald, and D. Macherel. 2005. Identification in pea seed mitochondria of a late-embryogenesis abundant protein able 
to protect enzymes from drying. Plant Physiol 137:157-167. doi:10.1104/pp.104.052480.

$\rightarrow$ Hand S.C., D. Jones, M.A. Menze, and T.L. Witt. 2007. Life without water: expression of plant LEA genes by an anhydrobiotic arthropod. J Exp Zool A 307A:62-66. doi:10.100 /jez.a.343.

$\rightarrow$ Hand S.C., M.A. Menze, M. Toner, L. Boswell, and D. Moore. 2011. LEA proteins during water stress: not just for plants anymore. Annu Rev Physiol 73:115-134. doi:10.114t /annurev-physiol-012110-142203.

$\rightarrow$ Hengherr S., A.G. Heyer, H.R. Köhler, and R.O. Schill. 2008. Trehalose and anhydrobiosis in tardigrades-evidence for divergence in responses to dehydration. FEBS J 275:281-288 $\rightarrow$ doi:10.1111/j.1742-4658.2007.06198.x.

$\rightarrow$ Hincha D.K. and A. Thalhammer. 2012. LEA proteins: IDPs with versatile functions in cellular dehydration tolerance. Biochem Soc Trans 40:1000-1003. doi:10.1042/bst20120109.

$\rightarrow$ Honjoh K., H. Matsumoto, H. Shimizu, K. Ooyama, K. Tanaka, Y. Oda, R. Takata, et al. 2000. Cryoprotective activities o $\rightarrow$ group 3 late embryogenesis abundant proteins from Chlorella vulgaris C-27. Biosci Biotechnol Biochem 64:1656-1663. doi: 10.1271/bbb.64.1656.

$\rightarrow$ Hundertmark M., A.V. Popova, S. Rausch, R. Seckler, and D.K. Hincha. 2012. Influence of drying on the secondary structur $\rightarrow$ of intrinsically disordered and globular proteins. Biochem Biophys Res Commun 417:122-128. doi:10.1016/j.bbrc .2011.11.067.

$\rightarrow$ Ismail A.M., A.E. Hall, and T.J. Close. 1999. Purification and partial characterization of a dehydrin involved in chilling tolerance during seedling emergence of cowpea. Plant Physiol 120:237-244. doi:10.1104/pp.120.1.237.

$\rightarrow$ Kentsis A. and T.R. Sosnick. 1998. Trifluoroethanol promotes helix formation by destabilizing backbone exposure: desol vation rather than native hydrogen bonding defines the kinetic pathway of dimeric coiled coil folding. Biochemistry 37:14613-14622. doi:10.1021/bi981641y.

$\rightarrow$ Lapinski J. and A. Tunnacliffe. 2003. Anhydrobiosis without trehalose in bdelloid rotifers. FEBS Lett 553:387-390. doi: 10.1016/s0014-5793(03)01062-7.

$\rightarrow$ Li D.X. and X.M. He. 2009. Desiccation induced structural alterations in a 66-amino acid fragment of an anhydrobiotic nematode late embryogenesis abundant (LEA) protein Biomacromolecules 10:1469-1477. doi:10.1021/bm9002688.

$\rightarrow$ Liu Y., S. Chakrabortee, R.H. Li, Y.Z. Zheng, and A. Tunnacliffe. 2011. Both plant and animal LEA proteins act as kinetic stabilisers of polyglutamine-dependent protein aggregation. FEBS Lett 585:630-634. doi:10.1016/j.febslet.2011.01.020.

$\rightarrow$ Madin K.A.C. and J.H. Crowe. 1975. Anhydrobiosis in nematodes: carbohydrate and lipid metabolism during dehydration. J Exp Zool 193:335-342. doi:10.1002/jez.1401930309.

$\rightarrow$ Marunde M.R., D.A. Samarajeewa, J. Anderson, S.M. Li, S.C $\rightarrow$ Hand, and M.A. Menze. 2013. Improved tolerance to salt and water stress in Drosophila melanogaster cells conferred by late embryogenesis abundant protein. J Insect Physiol 59: 377-386. doi:10.1016/j.jinsphys.2013.01.004.

$\rightarrow$ Menze M.A., L. Boswell, M. Toner, and S.C. Hand. 2009. Oc- currence of mitochondria-targeted late embryogenesis abundant (LEA) gene in animals increases organelle resistance to water stress. J Biol Chem 284:10714-10719. doi:10.1074/jbc .C900001200.

$\rightarrow$ Miller D.P., R.E. Anderson, and J.J. de Pablo. 1998. Stabilization of lactate dehydrogenase following freeze-thawing and vacuum-drying in the presence of trehalose and borate. Pharm Res 15:1215-1221. doi:10.1023/a:1011987707515.

$\rightarrow$ Nakayama K., K. Okawa, T. Kakizaki, T. Honma, H. Itoh, and T. Inaba. 2007. Arabidopsis Cor15am is a chloroplast stromal protein that has cryoprotective activity and forms oligomers. Plant Physiol 144:513-523. doi:10.1104/pp.106.094581.

Popova A.V., M. Hundertmark, R. Seckler, and D.K. Hincha. 2011. Structural transitions in the intrinsically disordered plant dehydration stress protein LEA7 upon drying are modulated by the presence of membranes. Biochim Biophys Acta Biomembr 1808:1879-1887. doi:10.1016/j.bbamem.2011.03 .009 .

$\rightarrow$ Pouchkina-Stantcheva N.N., B.M. McGee, C. Boschetti, D. Tolleter, S. Chakrabortee, A.V. Popova, F. Meersman, D. Macherel, D.K. Hincha, and A. Tunnacliffe. 2007. Functional divergence of former alleles in an ancient asexual invertebrate. Science 318:268-271. doi:10.1126/science.1144363.

$\rightarrow$ Provencher S.W. and J. Glockner. 1981. Estimation of globular protein secondary structure from circular dichroism. Biochemistry 20:33-37. doi:10.1021/bi00504a006.

$\rightarrow$ Reyes J.L., M.J. Rodrigo, J.M. Colmenero-Flores, J.V. Gil, A. Garay-Arroyo, F. Campos, F. Salamini, D. Bartels, and A.A. Covarrubias. 2005. Hydrophilins from distant organisms can protect enzymatic activities from water limitation effects in vitro. Plant Cell Environ 28:709-718. doi:10.1111/j.1365 -3040.2005.01317.x.

$\rightarrow$ Sanchez-Ballesta M.T., M.J. Rodrigo, M.T. LaFuente, A. Granell, and L. Zacarias. 2004. Dehydrin from Citrus, which confers in vitro dehydration and freezing protection activity, is constitutive and highly expressed in the flavedo of fruit but responsive to cold and water stress in leaves. J Agric Food Chem 52:1950-1957. doi:10.1021/jf035216.

$\rightarrow$ Savitzky A. and M.J.E. Golay. 1964. Smoothing and differentiation of data by simplified least squares procedures. Anal Chem 36:1627-1639. doi:10.1021/ac60214a047.

Shih M.D., T.Y. Hsieh, W.T. Jian, M.T. Wu, S.J. Yang, F.A. Hoekstra, and Y.I.C. Hsing. 2012. Functional studies of soybean (Glycine max L.) seed LEA proteins GmPM6, GmPM11, and GmPM30 by CD and FTIR spectroscopy. Plant Sci 196:152159. doi:10.1016/j.plantsci.2012.07.012.

$\rightarrow$ Shih M.D., S.D. Lin, J.S. Hsieh, C.H. Tsou, T.Y. Chow, T.P. Lin, and Y.I.C. Hsing. 2004. Gene cloning and characterization of a soybean (Glycine max L.) LEA protein, GmPM16. Plant Mol Biol 56:689-703. doi:10.1007/s11103-004-4680-3.

$\rightarrow$ Sreerama N., S.Y. Venyaminov, and R.W. Woody. 1999. Estimation of the number of $\alpha$-helical and $\beta$-strand segments in proteins using circular dichroism spectroscopy. Protein Sci 8:370-380.

$\rightarrow$ Sreerama N. and R.W. Woody. 2000. Estimation of protein secondary structure from circular dichroism spectra: com- 
parison of CONTIN, SELCON, and CDSSTR methods with an expanded reference set. Anal Biochem 287:252-260. doi: 10.1006/abio.2000.4880.

$\rightarrow$ Takeda K., M. Shigeta, and K. Aoki. 1987. Secondary structures of bovine serum albumin in anionic and cationic surfactant solutions. J Colloid Interface Sci 117:120-126. doi:10.1016 /0021-9797(87)90174-3.

$\rightarrow$ Thalhammer A., M. Hundertmark, A.V. Popova, R. Seckler, and D.K. Hincha. 2010. Interaction of two intrinsically disordered plant stress proteins (COR15A and COR15B) with lipid membranes in the dry state. Biochim Biophys Acta Biomembr 1798:1812-1820. doi:10.1016/j.bbamem.2010 .05 .015 .

$\rightarrow$ Tolleter D., D.K. Hincha, and D. Macherel. 2010. A mitochondrial late embryogenesis abundant protein stabilizes model membranes in the dry state. Biochim Biophys Acta Biomembr 1798:1926-1933. doi:10.1016/j.bbamem.2010 .06 .029 .

$\rightarrow$ Tolleter D., M. Jaquinod, C. Mangavel, C. Passirani, P. Saulnier, S. Manon, E. Teyssier, N. Payet, M.H. Avelange-Macherel, and D. Macherel. 2007. Structure and function of a mito. chondrial late embryogenesis abundant protein are revealed by desiccation. Plant Cell 19:1580-1589. doi:10.1105/tpc .107 .050104 .

$\rightarrow$ Tompa P. and D. Kovacs. 2010. Intrinsically disordered chaperones in plants and animals. Biochem Cell Biol 88:167-174 doi:10.1139/o09-163.

Tunnacliffe A., D.K. Hincha, O. Leprince, and D. Macherel. 2010. LEA proteins: versatility of form and function. Pp. 91108 in E. Lubzens, J. Cerda, and M. Clark, eds. Sleepin beauties: dormancy and resistance in harsh environments. Springer, Berlin.

$\rightarrow$ Tunnacliffe A. and M.J. Wise. 2007. The continuing conundrum of the LEA proteins. Naturwissenschaften 94:791-812. doi: 10.1007/s00114-007-0254-y.

$\rightarrow$ Uversky V.N. and A.K. Dunker. 2010. Understanding protein non-folding. Biochim Biophys Acta Proteins Proteomics 1804:1231-1264. doi:10.1016/j.bbapap.2010.01.017.

$\rightarrow$ van Stokkum I.H.M., H.J.W. Spoelder, M. Bloemendal, R. van Grondelle, and F.C.A. Groen. 1990. Estimation of protein secondary structure and error analysis from circular dichroism spectra. Anal Biochem 191:110-118. doi:10.1016/0003 -2697(90)90396-q.

$\rightarrow$ Whitmore L. and B.A. Wallace. 2004. DICHROWEB, an online server for protein secondary structure analyses from circular dichroism spectroscopic data. Nucleic Acids Res 32:W668W673. doi:10.1093/nar/gkh371.

$\rightarrow-2008$. Protein secondary structure analyses from circular dichroism spectroscopy: methods and reference databases. Biopolymers 89:392-400. doi:10.1002/bip.20853.

$\rightarrow$ Wise M.J. 2003. LEAping to conclusions: a computational reanalysis of late embryogenesis abundant proteins and their possible roles. BMC Bioinform 4:52. doi:10.1186/1471-2105-4 -52 .

Wolkers W.F., S. McCready, W.F. Brandt, G.G. Lindsey, and F.A. Hoekstra. 2001. Isolation and characterization of a D-7 LEA protein from pollen that stabilizes glasses in vitro. Biochim Biophys Acta Protein Struct Mol Enzym 1544:196-206. doi: 10.1016/s0167-4838(00)00220-x.

Yancey P.H. 2005. Organic osmolytes as compatible, metabolic and counteracting cytoprotectants in high osmolarity and other stresses. J Exp Biol 208:2819-2830. doi:10.1242/jeb .01730 .

Yancey P.H., M.E. Clark, S.C. Hand, R.D. Bowlus, and G.N. Somero. 1982. Living with water stress: evolution of osmolyte systems. Science 217:1214-1222. doi:10.1126/science .7112124 . 